\title{
B7-H3 and B7-H4 Expression in Breast Cancer and Their Association with Clinicopathological Variables and T Cell Infiltration
}

\author{
Nah Ihm Kima ${ }^{\mathrm{a}}$ Min Ho Park ${ }^{\mathrm{b}}$ Sun-Seog Kweon ${ }^{\mathrm{c}}$ Ji Shin Lee ${ }^{\mathrm{a}}$ \\ aDepartment of Pathology, Chonnam National University Medical School, Gwangju, South Korea; \\ ${ }^{b}$ Department of Surgery, Chonnam National University Medical School, Gwangju, South Korea; \\ 'Department of Preventive Medicine, Chonnam National University Medical School, Gwangju, South Korea
}

\section{Keywords}

B7-H3 · B7-H4 · Breast cancer · Outcomes · Immune surveillance

\begin{abstract}
Objectives: $\mathrm{B} 7-\mathrm{H} 3$ and $\mathrm{B} 7-\mathrm{H} 4$ proteins are expressed in breast cancer tissues, but their relationships with respect to tumor immune surveillance and outcomes in breast cancer are not conclusive. Methods: We first examined B7-H3 and B7-H4 mRNA expression in the Genotype-Tissue Expression (GTEx) and The Cancer Genome Atlas (TCGA) datasets. Next, mRNA and protein expression were assessed by RNAscope in situ hybridization (ISH) and immunohistochemistry in 10 pairs of breast cancer and matched normal tissues. Immunohistochemical staining of $\mathrm{B} 7-\mathrm{H} 3, \mathrm{~B} 7-\mathrm{H} 4, \mathrm{CD} 3$, and $\mathrm{CD} 8$ was performed in tissue microarray slides containing 198 breast cancer samples. Association of $\mathrm{B} 7-\mathrm{H} 3$ and $\mathrm{B} 7-\mathrm{H} 4$ expression with survival was verified using the publicly accessible BreastMark tool. Results: $\mathrm{B} 7-\mathrm{H} 3$ and $\mathrm{B} 7-\mathrm{H} 4$ mRNA expression were significantly higher in breast cancer samples in the TCGA dataset than in normal breast tissues in the GTEx dataset. RNAscope ISH and immunohistochemistry showed that B7-H3 and B7-H4 mRNA and protein appeared to be mainly expressed in cancer cells. Expression of $\mathrm{B} 7-\mathrm{H} 3$ and $\mathrm{B} 7-\mathrm{H} 4$ tended to be associated with low-density scores of stromal
\end{abstract}

tumor-infiltrating lymphocytes (TILs) as well as molecular subtypes. Expressions of $\mathrm{B} 7-\mathrm{H} 3$ and $\mathrm{B} 7-\mathrm{H} 4$ were negatively correlated with stromal $\mathrm{CD} 3+$ and $\mathrm{CD} 8+\mathrm{T}$ cell infiltration density. B7-H3 and B7-H4 expression was not associated with survival, which was verified by BreastMark analysis. Conclusion: Expression levels of $\mathrm{B} 7-\mathrm{H} 3$ and $\mathrm{B} 7-\mathrm{H} 4$ were independent of clinical outcomes of breast cancer. There was an inverse relationship between the expression of $\mathrm{B} 7-\mathrm{H} 3$ and B7-H4 in breast cancer and the density of stromal TILs and CD8+ T lymphocytes. This inverse relationship may represent a promising target in the field of breast cancer immunotherapy.

(c) 2020 S. Karger AG, Basel

\section{Introduction}

Breast cancer is one of the most common malignancy in Korean women [1]. Despite the improvement in the overall survival and quality of life for women with breast cancer by various treatment modalities, breast cancer is still the leading cause of cancer deaths and therefore requires new therapeutic approaches [2].

In recent years, cancer immunotherapy is at the forefront of cancer treatment. The major types of cancer immunotherapy include monoclonal antibodies, cancer vac- karger@karger.com

www.karger.com/pat

(C) 2020 S. Karger AG, Base

Karger"
Ji Shin Lee

Department of Pathology, Chonnam National University Hwasun Hospital

322 Seoyang-ro, Hwasun-eup

Hwasun-gun, Gwangju, 58128 (South Korea)

jshinlee@ hanmail.net 
cines, and immune checkpoint inhibitors [3, 4]. Immune checkpoints are regulators of co-stimulatory or co-inhibitory signals that need to be activated or inactivated to initiate an immune response. Because immune checkpoint inhibitors can be upregulated by cancer cells and serve as an adaptive mechanism for cancer immune evasion, they can be promising targets for cancer immunotherapy [5].

$\mathrm{T}$ cell co-inhibitory molecules belonging to the $\mathrm{B} 7$ family provide critical inhibitory signals in the tumor microenvironment and activation of the programmed death 1 (PD-1) receptor by its ligand. PD ligand 1 (PD-L1, B7$\mathrm{H1}$ ) has been recognized as a major immune inhibitory mechanism in diverse solid malignancies [6-8]. Antibodies targeting the PD-1/PD-L1 pathway generate robust clinical responses in breast cancer, but only a subset of patients benefit from such therapy [9-12]. Efforts are now being made to combine PD-1/PD-L1 blockades with other drugs or modulators of immune checkpoints for breast cancer therapy [13-15].

Other B7 immunoregulatory families also are new promising therapeutic targets for developing immunotherapy. B7-H3 and B7-H4, co-regulatory ligands of the B7 family, can inhibit $\mathrm{T}$ cell activation and proliferation and downregulate T cell response [16, 17]. B7-H3 and B7$\mathrm{H} 4$ molecules have been implicated in tumor immunogenicity and cancer development. Recent studies have shown that $\mathrm{B} 7-\mathrm{H} 3$ and $\mathrm{B} 7-\mathrm{H} 4$ are differentially expressed in breast cancer tissues compared to normal tissue, but the relationships of $\mathrm{B} 7-\mathrm{H} 3$ and $\mathrm{B} 7-\mathrm{H} 4$ expression with respect to tumor immune surveillance and outcomes in breast cancer are not conclusive [18-26].

The present study evaluated the expression of B7-H3 and B7-H4 in breast cancer and their associations with clinicopathological features, outcomes, and T cell infiltration. The evaluation of B7-H3 and B7-H4 mRNA expression in breast cancer and normal subjects was performed in public datasets, and subsequently mRNA and protein expressions were assessed by RNAscope in situ hybridization (ISH) and immunohistochemistry in 10 pairs of breast cancer tissues and surrounding normal tissues. Expression levels of B7$\mathrm{H} 3$ and B7-H4 were immunohistochemically determined in 198 breast cancer samples with data available for estrogen receptor (ER), progesterone receptor (PR), and human epidermal growth factor receptor 2 (HER2) expression using tissue microarray (TMA). Immunohistochemical staining for $\mathrm{CD} 3$ and $\mathrm{CD} 8$ was also performed to investigate the roles of B7-H3 and B7-H4 in the regulation of T cell infiltration. Prognostic significance of B7-H3 and B7-H4 expression in patients with breast cancer was further analyzed using a publicly accessible dataset.

\section{Materials and Methods}

Transcriptome Analysis of B7-H3 and B7-H4 in Public

Datasets

B7-H3 and B7-H4 mRNA expression levels were measured in breast cancer tissues and normal breast tissues using a public database (www.proteinatlas.org) from which The Cancer Genome Atlas (TCGA) and Genotype-Tissue Expression (GTEx) information can be downloaded $[27,28]$. When comparing expression data from the TCGA and GTEx datasets, we used the Fragments Per Kilobase of transcripts per Million mapped reads. Dot box plots were generated to compare expression levels between cancer tissues and normal tissues of the breast.

B7-H3 and B7-H4 mRNA and Protein Expression in Breast Cancer Tissues and Their Matching Normal Breast Tissues Collection of Tissue Samples

Chonnam National University Hwasun Hospital Biobank, a member of the Korea Biobank Network, provided formalin-fixedparaffin-embedded (FFPE) samples of 10 pairs of breast cancer tissues and their corresponding normal breast tissues. Informed consent was obtained from all these 10 participants.

RNAscope ISH Assay

B7-H3 and B7-H4 mRNA transcripts were tested by ISH method using RNAscope FFPE assay kit (Advanced Cell Diagnostics, Hayward, CA, USA), as described previously [29-31]. RNAscope probes used for hybridization were as follows: Hs-B7-H3 (cat. 430411), Hs-B7-H4 (cat. 418081), positive control probe peptidylprolyl isomerase $\mathrm{B}$ (Hs-PPIB), and negative control probe bacterial dihydrodipicolinate reductase (DapB). Hybridization signals were visualized with RNAScope 2.0 HD Reagent Kit (Brown; Advanced Cell Diagnostics). A solution of 3,3'-diaminobenzidine and Gill's hematoxylin were used as chromogen and counterstain, respectively. FFPE HeLa cell pellet sections were used to verity the assay procedure.

Analysis of RNAscope amplification was performed semiquantitatively as follows: 0 , no staining or $<1 \mathrm{dot} / 10$ cells, $40 \times$; 1, 1-3 dots/cell, 20-40×; 2, 4-10 dots/cell, 20-40×; 3, >10 dots/ cell with $<10 \%$ of positive cells having dot clusters visible at $20 \times$; $4,>10$ dots/cell with $>10 \%$ of positive cells having dot clusters at $20 \times[30,31]$. Slides with a PPIB score of 2 or greater and DapB background score of 1 or less were considered to have passed the criteria for quality assessment of tissue mRNA and were included for analyzing B7-H3 and B7-H4 mRNA expression levels.

Immunohistochemistry

B7-H3 and B7-H4 immunohistochemical staining was performed using a Bond-max Autostainer (Leica Microsystems, Bannockburn, IL, USA) as described in the previous study [32]. B7-H3 (6A1, 1:800 dilution; Thermo Fisher Scientific, Rockford, IL, USA) and B7-H4 (D1M81, 1:200 dilution; Cell Signaling Technology, Danvers, MA, USA) monoclonal primary antibodies were used. As previously reported [33], B7-H3 and B7-H4 immunoreactivity was assessed semi-quantitatively based on the intensity of staining $(0$, no staining; 1 , light staining; 2 , moderate staining; 3 , strong staining) and the percentage of stained cells $(0,<5 \% ; 1,5-25 \% ; 2,25-$ $50 \% ; 3,>50 \%$; Fig. 1). The intensity and percent scores were multiplied to obtain a final staining score. 

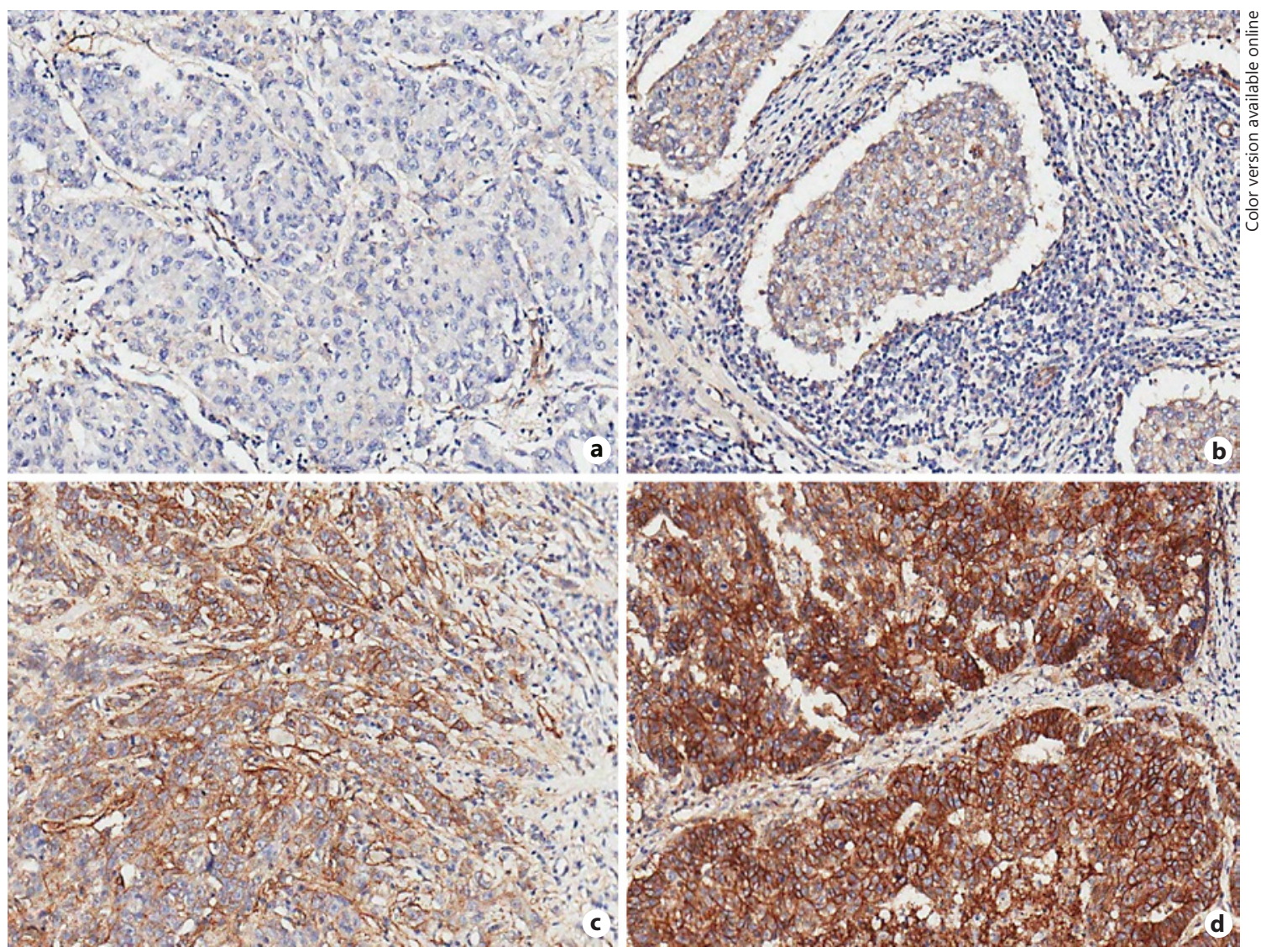

Fig. 1. Representative immunohistochemical staining for $\mathrm{B} 7-\mathrm{H} 3$ protein expression in breast cancer tissue. a Breast cancer cells with no staining. b Breast cancer cells with weak staining. c Breast cancer cells with moderate staining. d Breast cancer cells with strong staining. B7-H3 protein expression was detected in both the cell membrane and cytoplasm. $\mathbf{a}-\mathbf{d} \times 200$.

Expression of B7-H3, B7-H4, CD3, and CD8 in Breast Cancer Tissues

Patients and Tissues

FFPE breast cancer tissue samples $(n=198)$ were obtained from patients in Chonnam National University Hospital and Chonnam National University Hwasun Hospital, Korea.

Patients diagnosed with breast cancer from January 1997 to December 2002 were included in the study. After surgery, the patients underwent standard radiation therapy or adjuvant systemic therapy (hormone therapy or chemotherapy) according to medical insurance program controlled by the Ministry of Health and Welfare of Korea. Medical records were reviewed to obtain clinical information including patient outcome. Pathological characteristics were obtained from histopathology reports. Expression levels of ER- $\alpha$, PR, and HER2/neu were also collected. ER- $\alpha$ and PR were evaluated according to the Allred score [34], and tumors were considered positive for ER- $\alpha$ or PR when the total score was $>2$. HER2/ neu immunostaining was considered positive when strong $(3+)$ membranous staining was observed in at least $30 \%$ of tumor cells, whereas cases with $0-2+$ were regarded as negative [35]. Samples with HER2/neu 2+ immunohistochemical results have been retested by silver-enhanced ISH technique [36]. Cases with an abso- lute HER2 gene copy number $>6$ or an HER2/Chr 17 ratio $>2.2$ were considered as HER2 silver-enhanced ISH positive.

Breast cancers were classified into the following 4 subtypes according to hormone receptor (HR; ER or PR) and HER2 status: $\mathrm{HR}+/ \mathrm{HER} 2-$, HR+/HER2+, HR-/HER2+, and triple-negative (ER-/PR-/HER2-). The density of stromal tumor-infiltrating lymphocytes (TILs) was defined as the percentage of tumor stroma area that contained lymphocytic infiltrates without direct contact with carcinoma cells and were divided into 4 categories: 0 (no TILs), 1 ( $<5 \%$ stromal area with TILs), 2 (5-50\% stromal area with TILs), and 3 (>50\% stromal area with TILs) [37].

\section{TMA Construction}

For each case, one representative FFPE block was used to construct the TMA blocks. Three cores of $1 \mathrm{~mm}$ diameter were taken from each donor block.

Immunohistochemistry and Evaluation of

Immunohistochemical Staining

Serial sections of TMA blocks were used for immunohistochemistry as mentioned above. B7-H3 (6A1, 1:1,800 dilution; Thermo Fisher Scientific, Rockford, IL, USA), B7-H4 antibody (D1M81, 


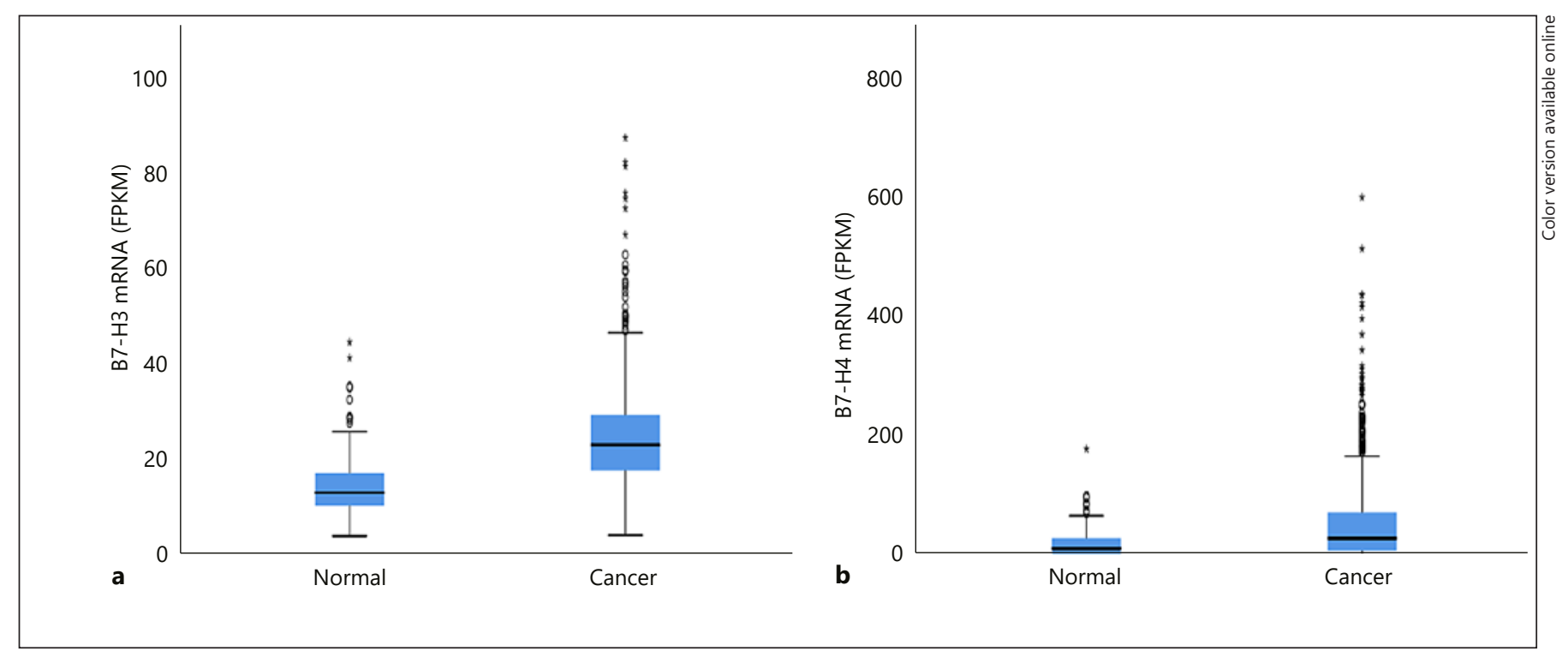

Fig. 2. Dot box plots of normal and cancer tissues of the breast, plotted using GTEx project and TCGA datasets showing B7-H3 (a) and B7-H4 (b) mRNA expression. The gene expression levels calculated from the FPKM. FPKM, Fragments Per Kilobase of transcript per Million.

1:100 dilution; Cell Signaling Technology, Danvers, MA, USA), CD3 (F7.2.38, 1:50 dilution; Dako, Carpinteria, CA, USA), and CD8 (C8/144B, 1:100 dilution; Dako, Carpinteria, CA, USA) primary antibodies were used. The immunostained slides were scanned using a slide scanner (Aperio Technologies, Vista, CA, USA). B7-H3 and B7-H4 immunoreactivity was assessed as described above, and the samples were classified into 2 groups as follows: low expression $(0-4$ score) and high expression ( $>4$ score) [33].

The density of CD3+ and CD8+ T cell infiltrates was semiquantitatively evaluated within tumor area. Tumor area is the area occupied by tumor cells as well as their associated intratumoral and contiguous peritumoral stroma [37]. The density of CD3+ and CD8+ T cell infiltrates were evaluated in tumor cells (intratumoral) and stroma (stromal), respectively. CD3+ and CD8+ T cells were counted and averaged per 3 high-power fields (hpfs) within the most dense areas. The densities were classified as follows: group $0, \leq 5$ cells/ 3 hpfs; group 1, 6-50 cells/3 hpfs; group 2, 51-99 cells/3 hpfs; and group 3, $\geq 100$ cells per 3 hpfs. Groups 0 and 1 were considered low density, while groups 2 and 3 were considered high density [19].

\section{Statistical Analysis}

Statistical analysis was performed by using the SPSS 13.5 software (SPSS INC., Chicago, IL, USA). Categorical nominal variables were tested using the $\chi^{2}$ or Fisher's exact test. The $t$ test was used for continuous variables with normal distribution. Mann-Whitney U test was used to assess differences in B7-H3 and B7-H4 mRNA and protein expression between breast cancers and their adjacent normal breast tissues. Spearman's correlation was used to evaluate the association between variables. The survival rates were plotted and compared using the KaplanMeier curves and the log-rank test, respectively. Results were considered statistically significant at a value of $p<0.05$ in all comparisons.
Validation of B7-H3 and B7-H4 for Prognostic Potential in Breast Cancer Using BreastMark

We used BreastMark dataset to validate the prognostic values of B7-H3 and B7-H4 in patients with breast cancer. This online database incorporates gene expression data corresponding to approximately 17,000 genes and survival data from 4,738 breast cancer samples [38]. Disease-free survival was analyzed, and median expression was used to dichotomize the data. Disease-free survival was analyzed for breast cancer in general and with respect to subgroups including 4 molecular subtypes including luminal A, luminal B, HER2, and basal groups. Survival curves were illustrated by Kaplan-Meier method, and differences in survival curves were compared using the log-rank test. Hazard ratios with 95\% CIs were computed using Cox regression analysis.

\section{Results}

\section{Transcriptome Analysis of B7-H3 and B7-H4 in}

\section{Public Datasets}

We compared the expression data of B7-H3 and B7$\mathrm{H} 4$ in breast cancer (TCGA, $n=1,075$ ) and normal breast (GTEx, $n=214$ ) datasets. B7-H3 expression was significantly higher in breast cancer tissues $(24.5 \pm 10.0)$ than in normal breast tissues $(14.4 \pm 6.1 ; p<0.001)$. Expression of B7-H4 was significantly increased in breast cancer tissues $(55.8 \pm 128.6)$ compared to normal breast tissues (17.2 \pm 22.6; $p<0.001$; Fig. 2) 


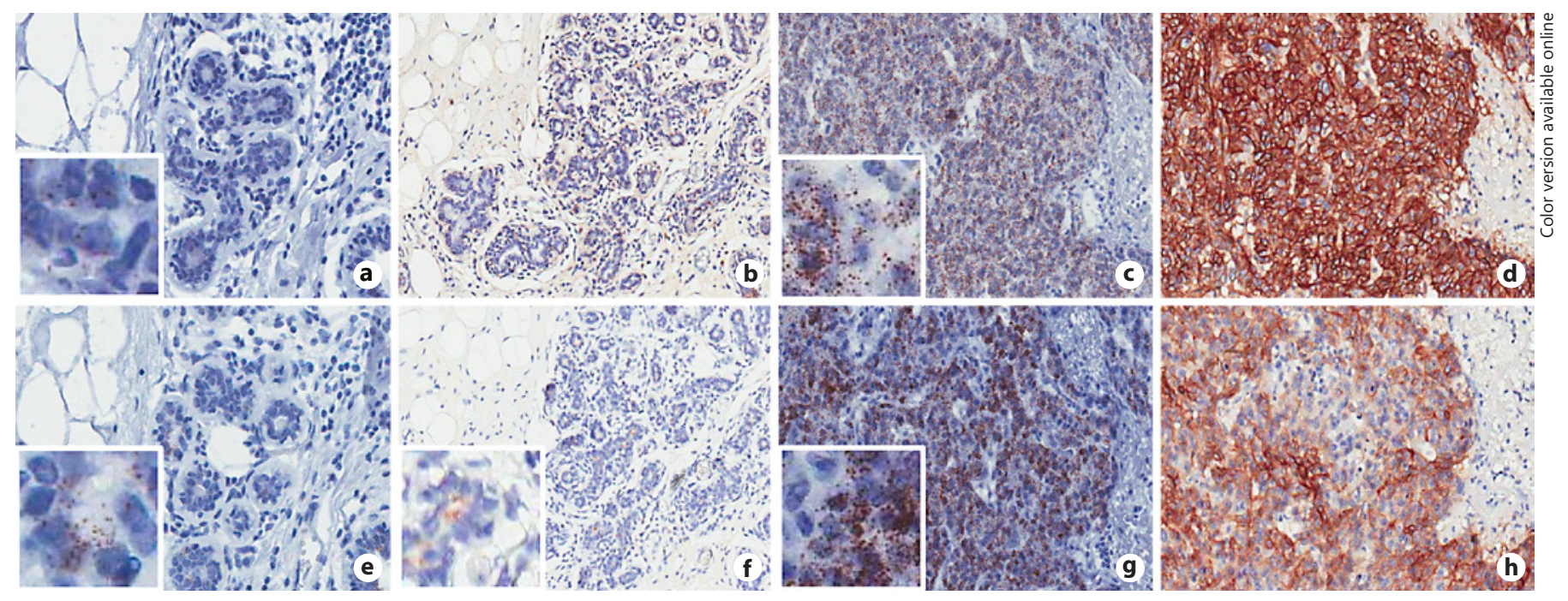

Fig. 3. Expression and localization of B7-H3 mRNA (a, c), B7-H3 protein (b, d), B7-H4 mRNA (e, g), and B7$\mathrm{H} 4$ protein $(\mathbf{f}, \mathbf{h})$ in normal $(\mathbf{a}, \mathbf{b}, \mathbf{e}, \mathbf{f})$ and cancer $(\mathbf{c}, \mathbf{d}, \mathbf{g}, \mathbf{h})$ tissues of the breast. mRNA and protein expression levels of B7-H3 and B7-H4 are higher in cancer tissues than in adjacent normal tissues. $\mathbf{b}-\mathbf{d}, \mathbf{f}-\mathbf{h}, \times 200 ; \mathbf{a}, \mathbf{e} \times 400$.

Table 1. B7-H3 and B7-H4 mRNA and protein expression in normal and cancer tissues of the breast

\begin{tabular}{|c|c|c|c|c|c|c|c|c|}
\hline \multirow[t]{2}{*}{ Case no. } & \multicolumn{4}{|l|}{ B7-H3 } & \multicolumn{4}{|l|}{ B7-H4 } \\
\hline & normal & cancer & normal & cancer & normal & cancer & normal & cancer \\
\hline 1 & 1 & 1 & 1 & 2 & 1 & 1 & 0 & 0 \\
\hline 2 & 1 & 2 & 2 & 2 & 2 & 2 & 0 & 0 \\
\hline 3 & 1 & 2 & 1 & 2 & 2 & 2 & 0 & 0 \\
\hline 5 & 1 & 3 & 1 & 9 & 1 & 4 & 1 & 8 \\
\hline 6 & 1 & 2 & 1 & 4 & 1 & 2 & 0 & 5 \\
\hline 7 & 1 & 2 & 2 & 4 & 1 & 2 & 2 & 3 \\
\hline 8 & 1 & 2 & 4 & 5 & 2 & 4 & 0 & 9 \\
\hline 9 & 1 & 3 & 1 & 5 & 1 & 2 & 0 & 3 \\
\hline 10 & 1 & 3 & 2 & 5 & 1 & 3 & 1 & 8 \\
\hline
\end{tabular}

ISH, in situ hybridization; IHC, immunohistochemistry.

B7-H3 and B7-H4 mRNA and Protein Expression in Breast Cancer Tissues and Their Adjacent Normal Breast Tissues

To investigate the expression and location of B7-H3 and $\mathrm{B} 7-\mathrm{H} 4$ mRNA and protein in 10 breast cancers and their adjacent normal breast tissues, ISH and immunohistochemical analyses were performed. FFPE HeLa cell pellet sections hybridized with PPIB probe showed positive signals, while those hybridized with DapB probe showed no signal. All 10 samples passed the criteria for quality assessment of tissue mRNA. Therefore, they were included in the analysis of B7-H3 and B7-H4 mRNA expression.

B7-H3 and B7-H4 mRNA ISH signals were mainly detected in the epithelium of normal and cancer issues (Fig. 3a, c, e, g). In some cases, B7-H3 mRNA signal was also observed in the stromal component of cancer tissues, especially in endothelial cells. Because the levels of stro- 
Table 2. Relationship between B7-H3 and B7-H4 expression and clinicopathological variables in patients with breast cancer

\begin{tabular}{|c|c|c|c|c|}
\hline Variables & $\begin{array}{l}\text { High B7-H3 expression } \\
n / \text { total } n(\%)\end{array}$ & $p$ value* & $\begin{array}{l}\text { High B7-H4 expression } \\
n / \text { total } n(\%)\end{array}$ & $p$ value* \\
\hline Age, years & & ns & & ns \\
\hline$\leq 46$ & $82 / 112(73.2)$ & & $50 / 112(44.6)$ & \\
\hline$>46$ & $63 / 85(74.1)$ & & $41 / 86(48.2)$ & \\
\hline Histopathologic type & & ns & & ns \\
\hline Invasive carcinoma, NOS & $123 / 170(72.4)$ & & $74 / 170(43.5)$ & \\
\hline Invasive lobular carcinoma & $20 / 25(80.0)$ & & $15 / 25(60.0)$ & \\
\hline Mucinous carcinoma & $2 / 2(100)$ & & $2 / 2(100)$ & \\
\hline Stromal TILs density score & & 0.034 & & ns \\
\hline 1 & $94 / 124(75.8)$ & & $61 / 124(49.2)$ & \\
\hline 2 & $48 / 62(77.4)$ & & $27 / 62(43.5)$ & \\
\hline 3 & $3 / 11(27.3)$ & & $3 / 11(27.3)$ & \\
\hline Tumor size, $\mathrm{cm}$ & & ns & & ns \\
\hline$\leq 2$ & $24 / 35(68.64)$ & & $18 / 35(51.4)$ & \\
\hline $2-5$ & $97 / 132(73.5)$ & & $55 / 132(41.7)$ & \\
\hline$>5$ & $24 / 30(80.0)$ & & $18 / 30(60.0)$ & \\
\hline Number of nodal metastasis & & ns & & ns \\
\hline 0 & 77/104 (74.0) & & $52 / 104(50.0)$ & \\
\hline $1-3$ & $39 / 51(76.5)$ & & 20/51 (39.2) & \\
\hline $4-9$ & $17 / 25(68.0)$ & & $9 / 25(30.0)$ & \\
\hline$\geq 10$ & $12 / 17(70.6)$ & & $10 / 17(58.8)$ & \\
\hline Histologic grade & & ns & & ns \\
\hline 1 & $18 / 26(69.2)$ & & $10 / 26(38.5)$ & \\
\hline 2 & $74 / 100(74.0)$ & & $49 / 100(49.0)$ & \\
\hline 3 & $53 / 71(74.6)$ & & $32 / 71(45.1)$ & \\
\hline \multicolumn{5}{|l|}{ Stage } \\
\hline I & $24 / 35(68.6)$ & ns & $18 / 35(51.4)$ & ns \\
\hline II & $85 / 111(76.6)$ & & $47 / 111(42.3)$ & \\
\hline III & $36 / 51(70.6)$ & & $26 / 51(51.0)$ & \\
\hline Molecular subtypes & & ns & & 0.041 \\
\hline HR+/HER2- & $84 / 119(70.6)$ & & $50 / 119(42.0)$ & \\
\hline $\mathrm{HR}+/ \mathrm{HER} 2+$ & $9 / 16(56.3)$ & & $4 / 16(25.0)$ & \\
\hline HR-/HER2+ & $17 / 20(85.0)$ & & $12 / 2060.0)$ & \\
\hline Triple-negative & $35 / 42(83.3)$ & & $25 / 42(59.5)$ & \\
\hline Distant metastatic relapse & & ns & & ns \\
\hline No & $108 / 145(74.5)$ & & $67 / 145(46.2)$ & \\
\hline Yes & $37 / 52(71.2)$ & & $24 / 52(46.2)$ & \\
\hline
\end{tabular}

* Analyzed by $\chi^{2}$ test.

ns, not significant; NOS, not otherwise specified; TILs, tumor-infiltrating lymphocytes; HR, hormone receptor; HER2, human epidermal growth factor receptor 2.

mal B7-H3 and B7-H4 mRNA were generally low, the remainder of this study focuses on the epithelial compartment only. Comparative analysis of $\mathrm{B} 7-\mathrm{H} 3$ and $\mathrm{B} 7-\mathrm{H} 4$ mRNA amplification scores revealed that B7-H3 and B7H4 mRNA expression levels in cancer tissues were higher than in their corresponding normal breast tissues (B7H3: $2.3 \pm 0.7$ vs. $1.0 \pm 0.0, p<0.001$; B $7-H 4: 2.5 \pm 1.0$ vs. $1.3 \pm 0.5, p<0.01$; Table 1). Similar results were observed when B7-H3 and B7-H4 immunohistochemically stained slides were examined. B7-H3 and B7-H4 expression levels were found on the cell membrane and/or in the cytoplasm of cancer cells (Fig. 3d, h). In contrast, B7-H3 and B7-H4 expression in normal breast epithelium was weak, and the predominant staining pattern of $\mathrm{B} 7-\mathrm{H} 4$ was apical membranous (Fig. 3b, f).

B7-H3 and B7-H4 immunohistochemical staining scores were significantly higher in cancer tissues compared with adjacent normal tissues (B7-H3: $4.7 \pm 2.6$ vs. 
Table 3. Relationship between B7-H3 and B7-H4 expression and intratumoral CD3+ and CD8+ T cell infiltrates in breast cancer

\begin{tabular}{|c|c|c|c|c|c|c|c|c|c|c|c|c|c|c|}
\hline & \multicolumn{7}{|c|}{ Density of CD3+ T cell infiltrates*, \% } & \multicolumn{7}{|c|}{ Density of CD8+ T cell infiltrates*, \% } \\
\hline & group 0 & group 1 & group 2 & group 3 & $p$ value & high $^{* *}$ & $p$ value & group 0 & group 1 & group 2 & group 3 & $p$ value & high** & $p$ value \\
\hline B7-H3 expression & & & & & & & & & & & & & & ns \\
\hline Low $(n=52)$ & $39(75.0)$ & $13(25.0)$ & 0 & 0 & ns & 0 & ns & $43(82.7)$ & $9(17.3)$ & 0 & 0 & ns & 0 & ns \\
\hline High $(n=145)$ & $118(81.4)$ & $27(18.6)$ & 0 & 0 & & 0 & & $1,230(84.8)$ & $22(15.2)$ & 0 & 0 & & 0 & \\
\hline \multicolumn{15}{|l|}{ B7-H4 expression } \\
\hline Low $(n=106)$ & $86(81.1)$ & $20(18.9)$ & 0 & 0 & ns & 0 & ns & $91(85.8)$ & $15(14.2)$ & 0 & 0 & ns & 0 & ns \\
\hline $\operatorname{High}(n=91)$ & $71(78.0)$ & $20(22.0)$ & 0 & 0 & & 0 & & $75(82.4)$ & $16(17.6)$ & 0 & 0 & & 0 & \\
\hline \multicolumn{15}{|c|}{ B7-H3/B7-H4 expression } \\
\hline Low/low $(n=30)$ & $24(80.0)$ & $6(20.0)$ & 0 & 0 & ns & 0 & ns & $24(80.0)$ & $6(20.0)$ & 0 & 0 & ns & 0 & ns \\
\hline $\begin{array}{l}\text { Low/high or } \\
\text { high/low }(n=98)\end{array}$ & $80(81.6)$ & $18(18.4)$ & 0 & 0 & & 0 & & $86(87.8)$ & $12(12.2)$ & 0 & 0 & & 0 & \\
\hline High/high $(n=69)$ & $53(76.8)$ & $16(23.2)$ & 0 & 0 & & 0 & & $56(81.2)$ & $13(18.8)$ & 0 & 0 & & 0 & \\
\hline
\end{tabular}

* Group $0=\leq 5$ cells $/ 3 \mathrm{hpf}$, group $1=6-50$ cells $/ 3 \mathrm{hpf}$, group $2=51-99$ cells $/ 3 \mathrm{hpf}$, group $3=\geq 100 \mathrm{cells} / 3 \mathrm{hpf}$.

** High = groups 2 and 3 .

ns, not significant.

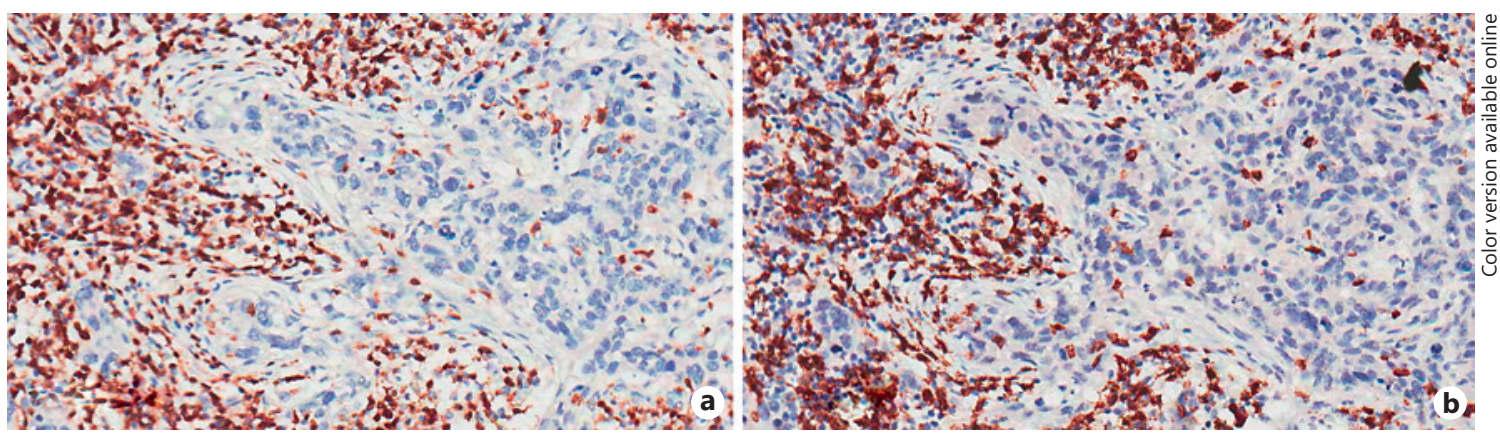

Fig. 4. Immunohistochemical localization of CD3+ (a) and CD8+ (b) T cells in breast cancer. CD3+ and CD8+ $\mathrm{T}$ cells are heavily infiltrated in the stromal compartment. However, a few CD3+ and CD8+ T cells are seen in the intratumoral area. $\mathbf{a}, \mathbf{b} \times 200$.

$1.7 \pm 0.9, p<0.01$; B7-H4: $4.4 \pm 3.7$ vs. $0.5 \pm 0.7, p<0.05$; Table 1). ISH and immunohistochemical staining scores of mRNA and protein of $\mathrm{B} 7-\mathrm{H} 3$ and $\mathrm{B} 7-\mathrm{H} 4$ in cancer tissues showed positive correlations (B7-H3: $r=0.758, p=$ 0.011; B7-H4: $r=0.868, p=0.001)$.

\section{Expression of B7-H3 and B7-H4 in Breast Cancer and Their Correlation with Infiltration of $\mathrm{CD} 3+$ and CD8+ T Cells}

Relationship between B7-H3 and B7-H4 Expression and Clinicopathological Features of Breast Cancer

Among 198 cases, 197 cases were examined for B7-H3 and $\mathrm{B} 7-\mathrm{H} 4$ expression. High levels of B7-H3 and B7-H4 expression were observed in $145(73.6 \%)$ and $91(46.2 \%)$ cases, respectively. Out of 197 cases, 69 (35.0\%) cases showed high expression for both B7-H3 and B7-H4, 76 (38.6\%) cases showed high expression for only B7-H3, 22 $(11.2 \%)$ cases showed high expression for only B7-H4, whereas 30 (15.2\%) cases showed low expression for both
B7-H3 and B7-H4. Although co-localization of B7-H3 and $\mathrm{B} 7-\mathrm{H} 4$ expression was observed in some of the breast cancer cases with high expression of both proteins, there was no positive or negative correlation between $\mathrm{B} 7-\mathrm{H} 3$ and $\mathrm{B} 7-\mathrm{H} 4$ expression.

The associations between $\mathrm{B} 7-\mathrm{H} 3$ and $\mathrm{B} 7-\mathrm{H} 4$ expression and clinicopathological variables in patients with breast cancer are shown in Table 2. B7-H3 and B7-H4 expression tended to be associated with low stromal TIL density scores and with molecular subtypes. Statistically significant associations were observed between high $\mathrm{B} 7-\mathrm{H} 3$ expression and low stromal TIL density scores and high B7-H4 expression and molecular subtypes ( $p<0.05$, both). B7-H3 and B7-H4 expression levels were higher in HR-/HER2+ and triplenegative subtypes. $\mathrm{B} 7-\mathrm{H} 3$ expression was increased in the triple-negative subtype than in the HR+/HER2+ subtype $(p<0.05)$. B7-H4 expression was also higher in the triplenegative subtype than in the HR+/HER2- and HR+/HER2+ subtypes ( $p<0.05$, both). B7-H4 expression was higher in 
Table 4. Relationship between B7-H3 and B7-H4 expression and stromal CD3+ and CD8+ T cell infiltrates in breast cancer

\begin{tabular}{|c|c|c|c|c|c|c|c|c|c|c|c|c|c|c|}
\hline & \multicolumn{7}{|c|}{ Density of CD3+ T cell infiltrates*, $\%$} & \multicolumn{7}{|c|}{ Density of CD8+ T cell infiltrates* } \\
\hline & group 0 & group 1 & group 2 & group 3 & $p$ value & high** & $p$ value & group 0 & group 1 & group 2 & group 3 & $p$ value & high** & $p$ value \\
\hline \multicolumn{15}{|l|}{ B7-H3 expression } \\
\hline Low $(n=52)$ & $2(3.8)$ & $20(38.5)$ & $18(34.6)$ & $12(23.1)$ & ns & $30(57.7)$ & ns & $2(3.8)$ & $29(55.8)$ & $12(23.1)$ & $9(17.3)$ & 0.020 & $21(40.4)$ & ns \\
\hline $\operatorname{High}(n=145)$ & $6(4.1)$ & $79(54.5)$ & $37(25.5)$ & $23(15.9)$ & & $60(41.4)$ & & $15(10.3)$ & $86(59.3)$ & $36(24.8)$ & $8(5.5)$ & & $44(30.3)$ & \\
\hline \multicolumn{15}{|l|}{ B7-H4 expression } \\
\hline Low $(n=106)$ & $3(2.8)$ & $48(45.3)$ & $35(33.0)$ & $20(18.9)$ & ns & $55(51.9)$ & 0.041 & $7(6.6)$ & $61(57.5)$ & $29(27.4)$ & $9(8.5)$ & ns & $38(35.8)$ & ns \\
\hline $\operatorname{High}(n=91)$ & $5(5.5)$ & $51(56.0)$ & $20(22.0)$ & $15(16.5)$ & & $35(38.5)$ & & $10(11.0)$ & $54(59.3)$ & $19(20.9)$ & $8(8.8)$ & & $27(29.7)$ & \\
\hline B7-H3/B7-H4 expression & & & & & ns & & $\mathrm{ns}$ & & & & & & & \\
\hline Low/low $(n=30)$ & $3(10.0)$ & $14(46.7)$ & $6(20.0)$ & $7(23.3)$ & & $13(43.3)$ & & $4(13.3)$ & $16(53.4)$ & $9(30.0)$ & $1(3.3)$ & $\mathrm{ns}$ & $10(33.3)$ & $\mathrm{ns}$ \\
\hline $\begin{array}{l}\text { Low/high or high/low } \\
(n=98)\end{array}$ & $1(1.0)$ & $46(46.9)$ & $34(34.7)$ & $17(17.3)$ & & $51(52.0)$ & & $5(5.1)$ & $58(59.2)$ & $25(25.5)$ & $10(10.2)$ & & $35(35.7)$ & \\
\hline High/high $(n=69)$ & $4(5.8)$ & $39(56.5)$ & $15(21.8)$ & $11(15.9)$ & & $26(37.7)$ & & $8(11.6)$ & $41(59.4)$ & $14(20.3)$ & $6(8.7)$ & & $20(29.0)$ & \\
\hline
\end{tabular}

* Group $0=\leq 5$ cells $/ 3 \mathrm{hpf}$, group $1=6-50$ cells $/ 3 \mathrm{hpf}$, group $2=51-99$ cells $/ 3 \mathrm{hpf}$, group $3=\geq 100$ cells $/ 3 \mathrm{hpf}$.

*** High $=$ groups 2 and 3 .

ns, not significant.
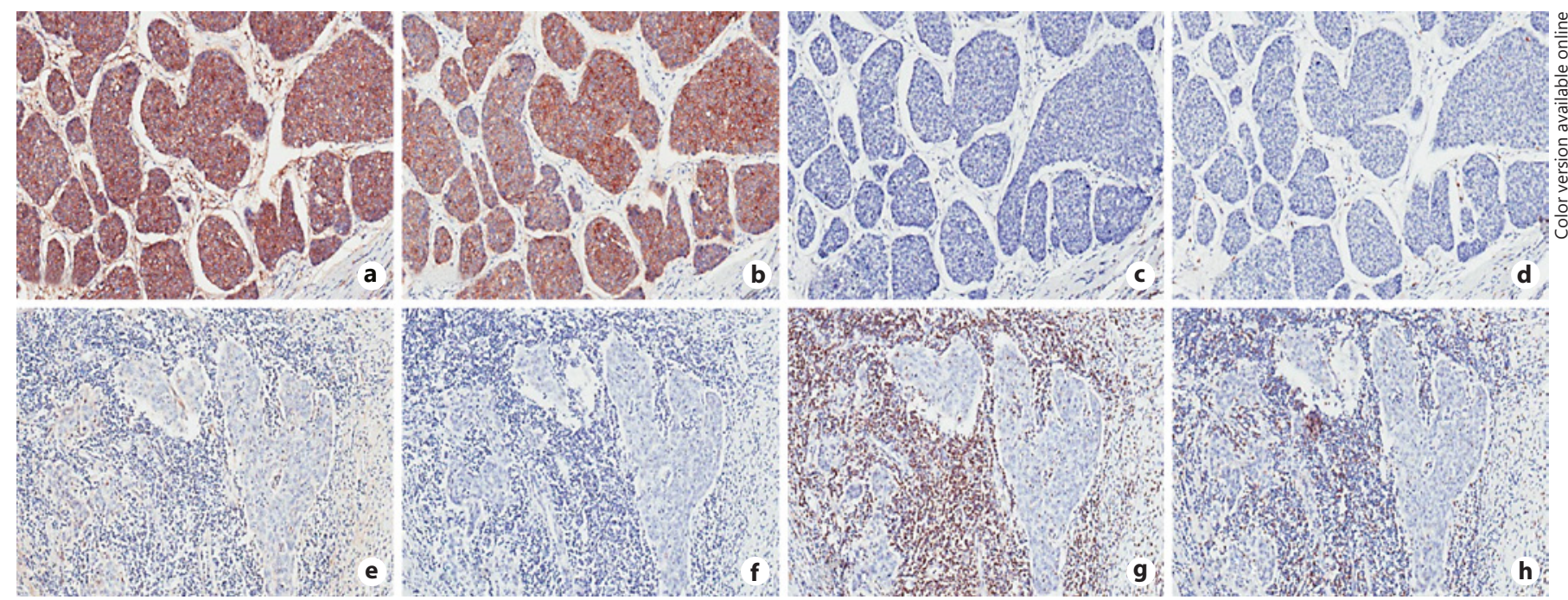

Fig. 5. Immunohistochemical localization of B7-H3 (a, e), B7-H4 (b, f), CD3+ T cells (c, g), and CD8+ T cells $(\mathbf{d}, \mathbf{h})$ in breast cancer. Numbers of CD3+ and CD8+ T cells in high B7-H3 (a) and B7-H4 (b) expression groups are lower compared to low B7-H3 (e) and B7-H4 (f) expression groups. $\mathbf{a}-\mathbf{h} \times 200$.

the HR-/HER2+ subtype than in the HR+/HER2+ subtype $(p<0.05)$. Other clinicopathological features were not found to be associated with B7-H3 and B7-H4 expression.

Correlation between B7-H3 and B7-H4 Expression and Infiltration of CD3+ and CD8+ T Cells

All cases had CD3+ and CD8+ T cells in the stromal area (Fig. 4). The number of stromal CD3+ T cells per 3 hpfs ranged from 1 to 221 (mean \pm SD $56.1 \pm 44.8$ ), and the number of stromal CD8+ T cells per $3 \mathrm{hpfs}$ ranged from 1 to 199 (mean \pm SD $43.5 \pm 38.8$ ). CD3+ and CD8+ $\mathrm{T}$ cells were also present in the intratumoral area in 126 and 97 cases, respectively. The number per $3 \mathrm{hpfs}$ ranged from 0 to 41 (mean \pm SD $4.3 \pm 7.6$ ) in intratumoral CD3+ $\mathrm{T}$ cells and from 0 to 49 (mean \pm SD $3.2 \pm 6.9$ ) in intratumoral CD8+ T cells. Based on the cutoff point, high-density CD3+ and CD8+ T cell infiltrates were found only in the stromal area and were observed in $90(45.7 \%)$ and 65 (32.9\%) cases out of 197 breast cancer cases (Tables 3, 4).

Correlation analysis of $\mathrm{B} 7-\mathrm{H} 3$ and $\mathrm{B} 7-\mathrm{H} 4$ expression and $\mathrm{CD} 3+$ and $\mathrm{CD} 8+\mathrm{T}$ cell infiltrates showed that $\mathrm{B} 7-\mathrm{H} 3$ and $\mathrm{B} 7-\mathrm{H} 4$ expression was negatively correlated with stromal CD3+ and CD8+ T cell infiltrate density (Table 4, Fig. 5). These correlations were statistically significant 
between $\mathrm{B} 7-\mathrm{H} 3$ expression and stromal CD8+ T cell infiltrate density $(p<0.05)$. High B7-H4 expression was associated with low stromal CD3+ T cell infiltrates $(p<$ 0.05). Co-expression of $\mathrm{B} 7-\mathrm{H} 3$ and $\mathrm{B} 7-\mathrm{H} 4$ did not increase the negative effect on stromal CD3+ and CD8+ T cell infiltration compared to expression of a single protein.

\section{Summary of Survival Analysis}

Tumor size, lymph node status, stage, and chemotherapy/radiotherapy status were significant risk factors affecting disease-free and overall survival of patients with breast cancer in univariate analysis (Table 5). Neither B7H3 nor B7-H4 expression was associated with diseasefree and overall survival (Fig. 6). Within 4 molecular subtypes, including the triple-negative subtype, the relationship between $\mathrm{B} 7-\mathrm{H} 3$ or $\mathrm{B} 7-\mathrm{H} 4$ expression and clinical outcome was not significant.

Following BreastMark analysis, B7-H3 and B7-H4 mRNA expression levels were analyzed in 1,178 and 2,281 patients with breast cancer, respectively. B7-H3 and B7H4 mRNA expression levels were not associated with disease-free survival in breast cancer patients in the entire group. Analysis of B7-H3 and B7-H4 mRNA expression levels with respect to parameters such as lymph node negative, lymph node positive, luminal A, luminal B, HER2, and basal subgroup did not demonstrate an association with survival (Fig. 7, 8). However, low B7-H4 expression levels in lymph node-negative group was associated with poor prognosis (hazard ratio $0.784, p=0.041, n=986$; Fig. 8).

\section{Discussion}

The relationship of $\mathrm{B} 7-\mathrm{H} 3$ and $\mathrm{B} 7-\mathrm{H} 4$ expression with respect to tumor immune surveillance and outcomes in breast cancer is not conclusive. In the present study, B7$\mathrm{H} 3$ and B7-H4 mRNA and protein expression levels were increased in cancer tissues compared with their normal breast counterparts. B7-H3 and B7-H4 expression levels tended to be associated with low stromal TIL density scores and stromal CD3+ and CD8+ $\mathrm{T}$ cell infiltrates. However, B7-H3 and B7-H4 expression levels were not associated with outcomes. Given the immune-inhibitory roles of $\mathrm{B} 7-\mathrm{H} 3$ and $\mathrm{B} 7-\mathrm{H} 4$, our results indicate that these molecules are attractive targets for breast cancer immunotherapy.

Despite advances in breast cancer treatment, effective therapies for advanced breast cancer have not yet been
Table 5. Univariate analysis of prognostic factors in patients with breast cancer

\begin{tabular}{lcr}
\hline & \multicolumn{2}{l}{ Survival } \\
\cline { 2 - 3 } & disease-free & overall \\
\hline Age, years & 0.978 & 0.552 \\
Histologic type & 0.078 & 0.419 \\
Stromal TIL density score & 0.279 & 0.149 \\
Tumor size & $<0.001$ & $<0.001$ \\
Lymph node status & $<0.001$ & $<0.001$ \\
Histologic grade & 0.524 & 0.103 \\
Stage & $<0.001$ & $<0.001$ \\
Hormonal therapy & 0.345 & 0.283 \\
Chemotherapy/radiotherapy & 0.024 & 0.016 \\
Molecular subtype & 0.473 & 0.177 \\
B7-H3 expression & 0.918 & 0.348 \\
B7-H4 expression & 0.898 & 0.555 \\
Stromal CD3+ T cell infiltrate & 0.702 & 0.440 \\
Stromal CD8+ T cell infiltrate & 0.475 & 0.215 \\
\hline
\end{tabular}

TIL, tumor-infiltrating lymphocytes.

established. Immunotherapy has become a treatment of choice for patients with advanced cancer $[3,4]$. Immune checkpoints are regulators of the immune system and are crucial for self-tolerance and antitumor immunity. Therefore, immune checkpoint inhibitors are targets for cancer immunotherapy [5].

The B7 family immune checkpoints are essential for tumor immune regulation. Tumors can suppress $\mathrm{T}$ cell response by expressing $\mathrm{B} 7 \mathrm{co}$-inhibitory molecules on tumor cell surfaces, leading to tumor immune evasion [7]. PD-1/PD-L1(B7-H1) pathway plays a major role in immune inhibitory mechanism in various human cancers [6-8]. Blockade of the PD-1/PD-L1 axis induces robust anticancer response and has recently become an effective alternative instead of the current conventional management that exists for advanced cancers [6-8]. Immunotherapy with $\mathrm{PD}-1 / \mathrm{PD}-\mathrm{L} 1$ pathway inhibitors has also shown clinical responses in breast cancer, but it appears to be beneficial only in a subset of breast cancer patients [9-12]. The combination of immune-checkpoint blockade with other drugs or targets of additional immune checkpoints is gaining attention in the treatment of breast cancer [13-15]. Recently, the Food and Drug Administration approved the combination therapy of atezolizumab, a monoclonal antibody drug targeting PD-L1 along with chemotherapy for the treatment of patients with PD-L1-positive, unresectable, locally advanced, or metastatic triple-negative breast cancer [15]. 



Fig. 6. Survival of breast cancer patients grouped according to B7-H3 (a, b) and B7-H4 expression (c, d). B7-H3 and B7-H4 expressions do not predict disease-free and overall survival.

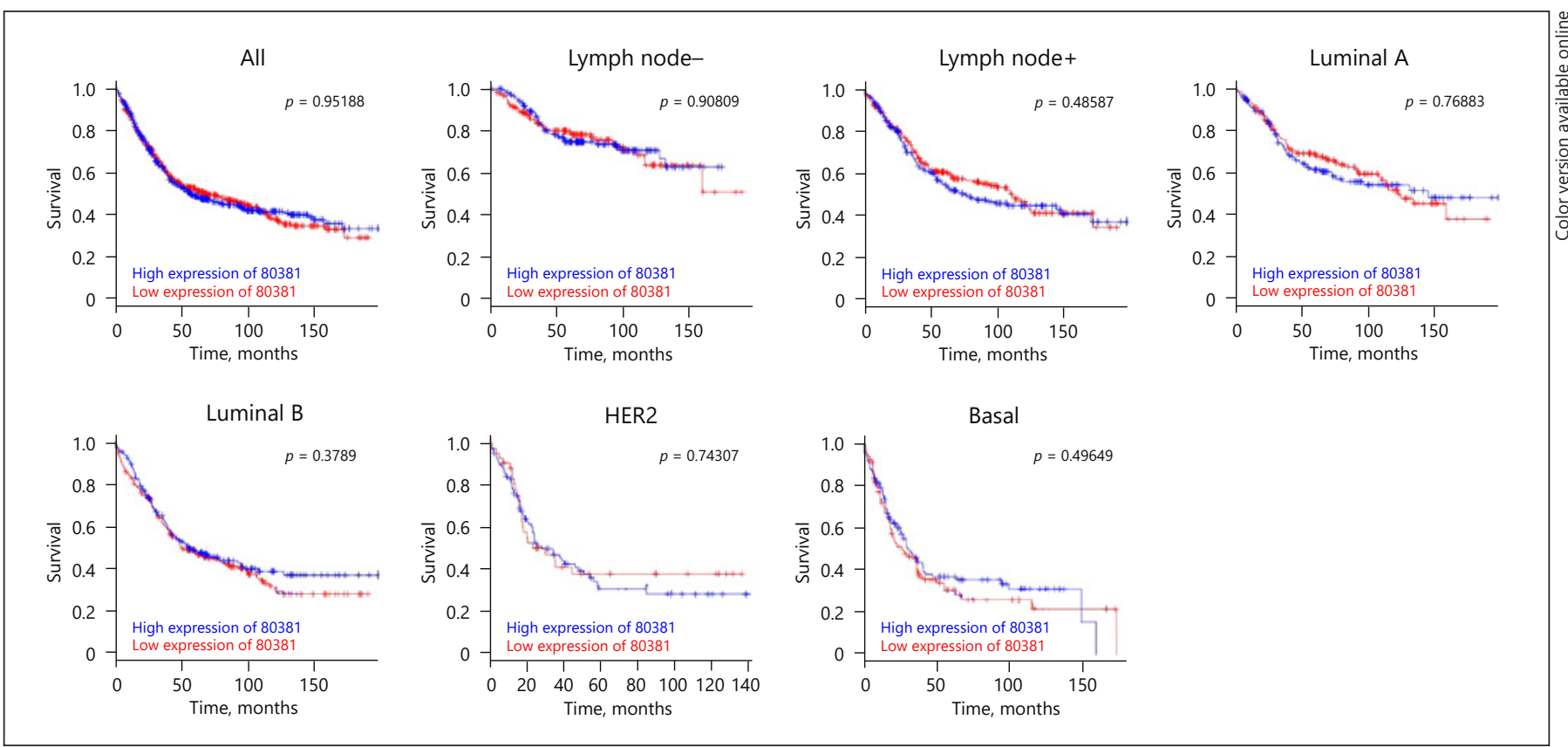

Fig. 7. Prognostic role of B7-H3 in breast cancer. These figures are generated using BreastMark. HER2, human epidermal growth factor receptor 2 . 


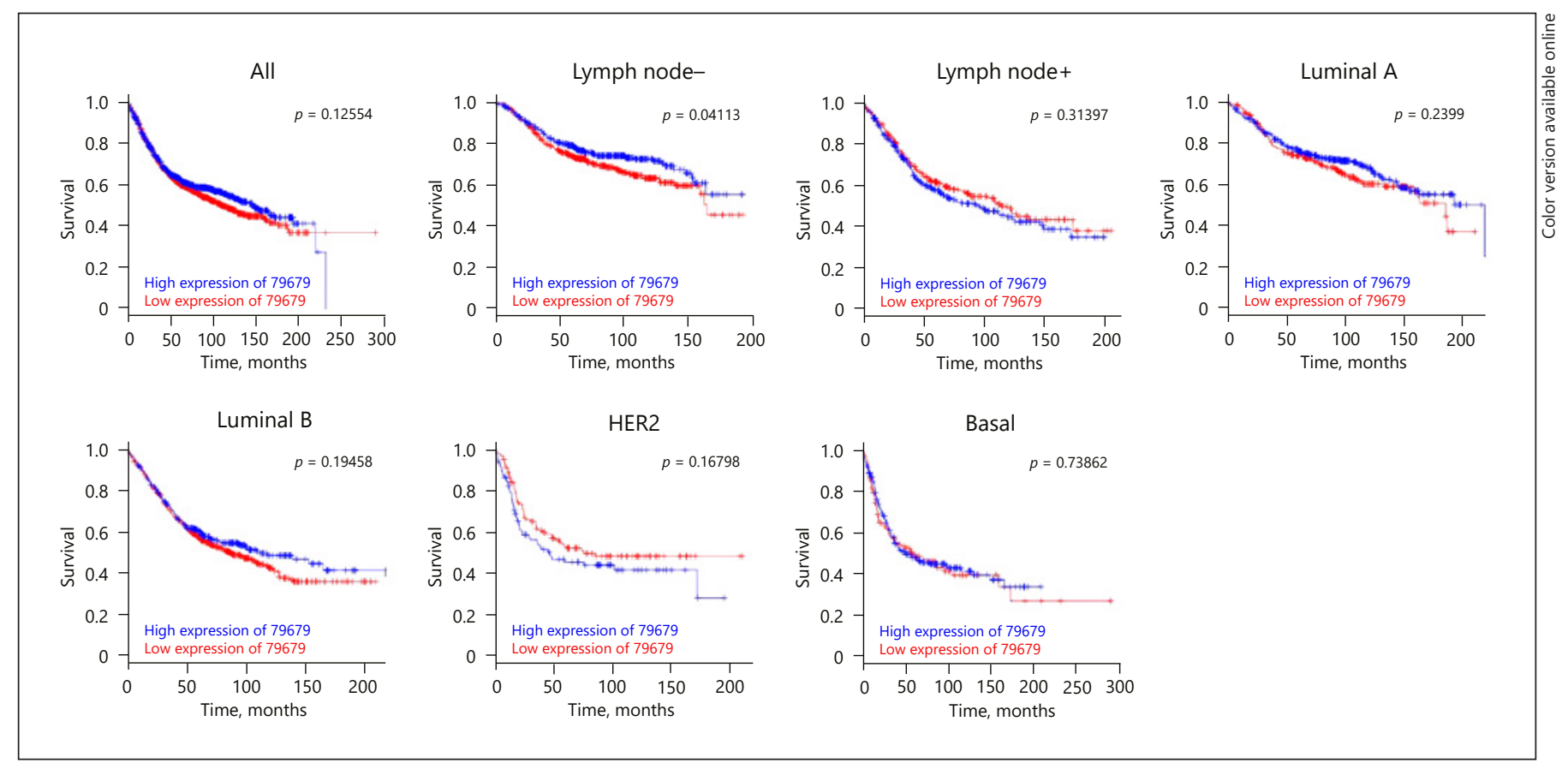

Fig. 8. Prognostic role of B7-H4 in breast cancer. These figures are generated using BreastMark. HER2, human epidermal growth factor receptor 2.

B7-H3 and B7-H4 are also important co-inhibitory molecules of the B7 family members in cancer immune surveillance and cancer development $[16,17]$. Several studies have explored the potential role of B7-H3 and B7$\mathrm{H} 4$ in breast cancer, but their relationships with respect to tumor immune surveillance and outcomes are not conclusive [18-26].

Expressions levels of $\mathrm{B} 7-\mathrm{H} 3$ and $\mathrm{B} 7-\mathrm{H} 4 \mathrm{mRNA}$ and protein as measured by quantitative PCR, western blot, immunohistochemistry, and multiplexed automated quantitative immunofluorescence are higher in breast cancer than in normal breast tissues [18-20, 22-24]. B7$\mathrm{H} 3$ protein expression was mainly observed on the cell membrane and in the cytoplasm [20-22, 24]. The expression pattern of B7-H4 in normal breast tissues was apical membranous, while the expression pattern in breast cancer was membranous and cytoplasmic $[18,19,23,25,26]$. Selective increase in B7-H3 and B7-H4 expression levels was observed only in cancer cells [18-25]. On the contrary, high $\mathrm{B} 7-\mathrm{H} 3$ protein expression in both tumor and stromal cells of breast cancer has also been reported [26].

First, we compared expression data of the B7-H3 and B7-H4 in TCGA breast cancer and GTEx normal breast datasets. The TCGA and GTEx data can be integrated for the most comprehensive expression analysis. Based on 1,075 breast cancer and 214 normal breast datasets, we confirmed that B7-H3 and B7-H4 mRNA expression levels were significantly higher in breast cancer tissues than in normal breast tissues. ISH and immunohistochemistry were performed to investigate the expression and location of $\mathrm{B} 7-\mathrm{H} 3$ and $\mathrm{B} 7-\mathrm{H} 4 \mathrm{mRNA}$ and protein in breast cancer and corresponding normal breast tissues. The main advantage of the RNAscope ISH technology is that it retains morphological features and has high sensitivity and specificity for the detection and quantification of mRNA expression at a single cell level [29-31]. Currently, there are no previous data on the use of RNAscope ISH method to detect B7-H3 and B7-H4 mRNA in breast cancer tissues.

In the present study, expression levels of $\mathrm{B} 7-\mathrm{H} 3$ and B7-H4 mRNA were mainly observed in the epithelium of normal and cancer tissues, but in some cases expression of B7-H3 mRNA was also observed in the stromal area, especially in endothelial cells. The staining patterns of B7$\mathrm{H} 3$ and $\mathrm{B} 7-\mathrm{H} 4$ protein as detected by immunohistochemistry were concordant with that of their mRNA expression as detected by RNAscope ISH. B7-H3 and B7-H4 $\mathrm{mRNA}$ and protein expression were increased in cancer tissues compared with their corresponding normal tissues. Moreover, B7-H3 and B7-H4 mRNA levels in cancer cells correlated with their protein levels. Our ISH and immunohistochemistry data confirmed that upregula- 
tion of $\mathrm{B} 7-\mathrm{H} 3$ and $\mathrm{B} 7-\mathrm{H} 4 \mathrm{mRNA}$ and protein occurs in tumor cells of breast cancer tissues. B7-H3 and B7-H4 expression in cancer tissues is primarily regulated at the transcriptional level, although the mechanisms underlying their expression remain unclear.

Upregulation of $\mathrm{B} 7-\mathrm{H} 3$ and $\mathrm{B} 7-\mathrm{H} 4$ expression could be associated with the clinical outcomes of cancer patients $[39,40]$. However, there have been conflicting reports on the prognostic significance of $\mathrm{B} 7-\mathrm{H} 3$ and $\mathrm{B} 7-\mathrm{H} 4$ expression in patients with breast cancer $[18,21,23,25,26]$. High or positive expression levels of $\mathrm{B} 7-\mathrm{H} 3$ and $\mathrm{B} 7-\mathrm{H} 4$ were associated with poor prognosis [21, 24, 25]. However, reports by Tringler et al. [18] and Altan et al. [26] did not show association between B7-H4 expression and survival. The reason for these discrepancies is unclear, but it could possibly be due to differences in the experimental methods, scoring system, and cutoff levels. Most of the methods used in the study were immunohistochemistry $[18,21,24$, $25]$. In one study, multiplexed automated quantitative immunosuppressive fluorescence was used [26]. Manual analysis $[21,24,25]$ or automated image analysis $[18,26]$ was performed to evaluate the expression. In studies using manual analysis, both staining intensity and proportion of stained cells were considered $[21,24,25]$. However, different cutoffs were used to distinguish positive (high) and negative (low) expressions.

In the present study, high B7-H3 and B7-H4 expression levels were observed in 73.6 and $46.2 \%$ of breast cancer samples, respectively. Neither B7-H3 nor B7-H4 expression was associated with disease-free and overall survival. The prognostic significance of $\mathrm{B} 7-\mathrm{H} 3$ and $\mathrm{B} 7-\mathrm{H} 4$ expression was further analyzed using the BreastMark database. Similar to our results, B7-H3 and B7-H4 mRNA expression levels were not associated with disease-free survival for patients with breast cancer in the entire group. Furthermore, subgroup analysis showed that $\mathrm{B} 7-\mathrm{H} 3$ and $\mathrm{B} 7-\mathrm{H} 4 \mathrm{mRNA}$ expression levels were not associated with survival except in the lymph node-negative subgroup. Interestingly, low levels of B7-H4 expression in patients with lymph nodenegative breast cancer correlated with poor prognosis.

In this study, B7-H3 and B7-H4 expression levels were observed to be associated with molecular subtypes. B7$\mathrm{H} 3$ and $\mathrm{B} 7-\mathrm{H} 4$ expression tended to be higher in the triple-negative subtype than in the HR+/HER2- and/or HR+/HER2+ subtypes. Our findings support studies by Tringler et al. [18] and Leong et al. [23], suggesting that B7-H3 and B7-H4 expression might be associated with triple-negative breast cancer phenotype. However, Altan et al. [26] found that B7-H4 protein expression was independent of ER/HER2 status.
Triple-negative breast cancer is a heterogeneous group and can be further stratified into distinct molecular subtypes including basal-like type [41]. Manipulation of the immune system represents a promising strategy for the treatment of triple-negative breast cancer [42]. To determine whether B7-H3 and B7-H4 can be targets for immunotherapy of triple-negative breast cancer, further studies are needed on a large cohort of various molecular subtypes of triple-negative breast cancer patients.

B7-H3 and B7-H4 are important in regulating antitumor responses by controlling $\mathrm{T}$ cell proliferation and function $[16,17]$. B7-H3 appears to downregulate T cell proliferation and cytokine production [16]. B7-H4 is also a T cell co-inhibitory molecule and can function as a co-inhibitory factor inhibiting CD4+ and CD8+ T cell proliferation by arresting the cell cycle [17]. However, studies of the relationship between TILs including CD3+ and CD8+ T lymphocytes and B7-H3/B7-H4 expression in breast cancer are few and results are not conclusive. Mugler et al. [19] have found a significant inverse correlation between $\mathrm{B} 7-\mathrm{H} 4$ protein expression and both $\mathrm{CD} 3+$ and $\mathrm{CD} 8+\mathrm{T}$ lymphocytes in breast cancer. Altan et al. [26] also found that TILs inversely correlated with B7-H4 expression in the University of Michigan cohort, albeit weakly. However, in the Yale cohort, they did not find an inverse correlation between TILs and B7-H4 expression. In the present study, expression of $\mathrm{B} 7-\mathrm{H} 3$ and $\mathrm{B} 7-\mathrm{H} 4$ tended to be associated with low stromal TIL density scores. B7-H3 and B7-H4 expression was negatively correlated with stromal CD3+ and CD8+ T cell infiltration density. Our results indicate that $\mathrm{B} 7-\mathrm{H} 3$ and B7-H4 expression in breast cancer can lead to tumor evasion from immunosurveillance through the suppression of T lymphocyte infiltration, particularly cytotoxic CD8+ T lymphocytes.

In the current study, $15.2 \%$ of breast cancer showed low expression for both $\mathrm{B} 7-\mathrm{H} 3$ and $\mathrm{B} 7-\mathrm{H} 4$. Because various immune checkpoints are promising targets for cancer immunotherapy [5], other immune checkpoints associated with TILs may be good candidates for further investigation to uncover new immunotherapeutic targets for breast cancer treatment.

In this study, we evaluated the expression of B7-H3 and B7-H4 in breast cancer and their correlation with infiltration of $\mathrm{CD} 3+$ and $\mathrm{CD} 8+\mathrm{T}$ cells in tumor area. Immunohistochemical staining was entirely done on TMAs, which is one of the limitations of this study. The use of TMAs may not provide the same information as if the expression patterns had been performed on whole sections. However, as in this study, some studies of B7-H4 expression in breast cancer have been performed in TMAs 
$[25,26]$. Recently, despite the limitations of TMAs, it has been suggested that TMAs may be a good option for the study of stromal TILs comparable with studies performed on whole sections [37].

In conclusion, $\mathrm{B} 7-\mathrm{H} 3$ and $\mathrm{B} 7-\mathrm{H} 4$ are more likely to be expressed in breast cancer tissue compared with normal breast tissues. Although $\mathrm{B} 7-\mathrm{H} 3$ and $\mathrm{B} 7-\mathrm{H} 4$ expressions are independent of clinical outcomes of breast cancer, high levels of B7-H3 and B7-H4 expression by cancer cells could impact $\mathrm{T}$ cell-mediated immune surveillance mechanisms through the suppression of tumor-infiltrating $\mathrm{T}$ lymphocytes, particularly cytotoxic CD8+ T lymphocytes. We suggest that $\mathrm{B} 7-\mathrm{H} 3$ and $\mathrm{B} 7-\mathrm{H} 4$ immune checkpoints could be attractive therapeutic targets for immunotherapy against breast cancer.

\section{Acknowledgments}

We would like to thank Editage (www.editage.co.kr) for English language editing. This study was supported by a grant (HCRI 19 001-119013) from the Chonnam National University Hwasun Hospital Institute for Biomedical Science.

\section{Statement of Ethics}

This study was approved by The Institutional Review Board at the Chonnam National University Hwasun Hospital (Jeollanamdo, Korea; Reference: CNUHH-2017-021). This retrospective study utilized archived materials and did not impact patient care; hence, it was granted our hospital Institutional Review Board approval without patient consent.

\section{Disclosure Statement}

The authors declare no conflict of interest.

\section{Author Contributions}

J.S.L. conceived the experiments. N.I.K. conducted the experiments. N.I.K., M.H.P., and S.S.K. analyzed the results. N.I.K. and J.S.L. wrote the manuscript. All authors reviewed the manuscript.

\section{References}

1 Park EH, Min SY, Kim Z, Yoon CS, Jung KW, Nam SJ, et al.; Korean Breast Cancer Society. Basic facts of breast cancer in Korea in 2014: the 10-year overall survival progress. J Breast Cancer. 2017 Mar;20(1):1-11.

2 Akram M, Iqbal M, Daniyal M, Khan AU. Awareness and current knowledge of breast cancer. Biol Res. 2017 Oct;50(1):33.

3 Mellman I, Coukos G, Dranoff G. Cancer immunotherapy comes of age. Nature. 2011 Dec; 480(7378):480-9.

4 Yousefi H, Yuan J, Keshavarz-Fathi M, Murphy JF, Rezaei N. Immunotherapy of cancers comes of age. Expert Rev Clin Immunol. 2017 Oct;13(10):1001-15.

5 Pardoll DM. The blockade of immune checkpoints in cancer immunotherapy. Nat Rev Cancer. 2012 Mar;12(4):252-64.

6 Sharpe AH, Wherry EJ, Ahmed R, Freeman GJ. The function of programmed cell death 1 and its ligands in regulating autoimmunity and infection. Nat Immunol. 2007 Mar;8(3):239-45.

7 Leung J, Suh WK. The CD28-B7 family in anti-tumor immunity: emerging concepts in cancer immunotherapy. Immune Netw. 2014 Dec;14(6):265-76.

8 Zou W, Wolchok JD, Chen L. PD-L1 (B7-H1) and PD-1 pathway blockade for cancer therapy: Mechanisms, response biomarkers, and combinations. Sci Transl Med. 2016 Mar; 8(328):328rv4.

9 Topalian SL, Hodi FS, Brahmer JR, Gettinger SN, Smith DC, McDermott DF, et al. Safety, activity, and immune correlates of anti-PD-1 antibody in cancer. N Engl J Med. 2012 Jun; 366(26):2443-54.

10 Nanda R, Chow LQ, Dees EC, Berger R, Gupta $\mathrm{S}, \mathrm{Geva}$ R, et al. Pembrolizumab in patients with advanced triple-negative breast cancer: phase Ib KEYNOTE-012 study. J Clin Oncol. 2016 Jul;34(21):2460-7.

11 Pusztai L, Karn T, Safonov A, Abu-Khalaf MM, Bianchini G. New strategies in breast cancer: immunotherapy. Clin Cancer Res. 2016 May;22(9):2105-10.

12 Pusztai L, Silber A, Hofstatter EW, Chung GG, Horowitz NR, Lannin DR, et al. Safety of MEDI4736 (anti-PD-L1 antibody) administered concomitant with weekly nab-paclitaxel and dose dense doxorubicin/cyclophosphamide (ddAC) as neoadjuvant chemotherapy for stage I-III triple negative breast cancer (TNBC): a Phase I/II trial. J Clin Oncol. 2017 Dec;35(15_suppl):572.

13 Vikas P, Borcherding N, Zhang W. The clinical promise of immunotherapy in triple-negative breast cancer. Cancer Manag Res. 2018 Dec; $10: 6823-33$.

14 Chrétien S, Zerdes I, Bergh J, Matikas A, Foukakis T. Beyond PD-1/PD-L1 inhibition: what the future holds for breast cancer immunotherapy. Cancers (Basel). 2019 May;11(5):628.

15 Cyprian FS, Akhtar S, Gatalica Z, Vranic S. Targeted immunotherapy with a checkpoint inhibitor in combination with chemotherapy: A new clinical paradigm in the treatment of triple-negative breast cancer. Bosn J Basic Med Sci. 2019 Aug;19(3):227-33.

16 Suh WK, Gajewska BU, Okada H, Gronski MA Bertram EM, Dawicki W, et al. The B7 family member B7-H3 preferentially down-regulates $\mathrm{T}$ helper type 1-mediated immune responses. Nat Immunol. 2003 Sep;4(9):899-906.

17 Zang X, Loke P, Kim J, Murphy K, Waitz R, Allison JP. B7x: a widely expressed B7 family member that inhibits T cell activation. Proc Natl Acad Sci USA. 2003 Sep;100(18):1038892.

18 Tringler B, Zhuo S, Pilkington G, Torkko KC, Singh M, Lucia MS, et al. B7-h4 is highly expressed in ductal and lobular breast cancer. Clin Cancer Res. 2005 Mar;11(5):1842-8.

19 Mugler KC, Singh M, Tringler B, Torkko KC, Liu W, Papkoff J, et al. B7-h4 expression in a range of breast pathology: correlation with tumor T-cell infiltration. Appl Immunohistochem Mol Morphol. 2007 Dec;15(4):363-70.

20 Arigami T, Narita N, Mizuno R, Nguyen L, Ye $\mathrm{X}$, Chung A, et al. B7-h3 ligand expression by primary breast cancer and associated with regional nodal metastasis. Ann Surg. 2010 Dec; 252(6):1044-51.

21 Maeda N, Yoshimura K, Yamamoto S, Kuramasu A, Inoue M, Suzuki N, et al. Expression of B7-H3, a potential factor of tumor immune evasion in combination with the number of regulatory $\mathrm{T}$ cells, affects against recurrencefree survival in breast cancer patients. Ann Surg Oncol. 2014 Dec;21(Suppl 4):S546-54. 
22 Sun J, Guo YD, Li XN, Zhang YQ, Gu L, Wu $\mathrm{PP}$, et al. B7-H3 expression in breast cancer and upregulation of VEGF through gene silence. OncoTargets Ther. 2014 Oct;7:197986.

23 Leong SR, Liang WC, Wu Y, Crocker L, Cheng E, Sampath D, et al. An anti-B7-H4 antibody-drug conjugate for the treatment of breast cancer. Mol Pharm. 2015 Jun;12(6): 1717-29.

24 Cong F, Yu H, Gao X. Expression of CD24 and $\mathrm{B} 7-\mathrm{H} 3$ in breast cancer and the clinical significance. Oncol Lett. 2017 Dec;14(6): 7185-90.

25 Huang H, Li C, Ren G. Clinical significance of the $\mathrm{B} 7-\mathrm{H} 4$ as a novel prognostic marker in breast cancer. Gene. 2017 Aug;623:24-8.

26 Altan M, Kidwell KM, Pelekanou V, CarvajalHausdorf DE, Schalper KA, Toki MI, et al. Association of B7-H4, PD-L1, and tumor infiltrating lymphocytes with outcomes in breast cancer. NPJ Breast Cancer. 2018 Dec;4(1):40.

27 Lonsdale J, Thomas J, Salvatore M, Phillips R, Lo E, Shad S, et al.; GTEx Consortium. The genotype-tissue expression (GTEx) project. Nat Genet. 2013 Jun;45(6):580-5.

28 Cancer Genome Atlas Network. Comprehensive molecular portraits of human breast tumours. Nature. 2012 Oct;490(7418):61-70.

29 Wang F, Flanagan J, Su N, Wang LC, Bui S, Nielson A, et al. RNAscope: a novel in situ RNA analysis platform for formalin-fixed, paraffin-embedded tissues. J Mol Diagn. 2012 Jan;14(1):22-9.
30 Kim NI, Kim GE, Lee JS, Park MH. In phyllodes tumors of the breast expression of SPARC (osteonectin/BM40) mRNA by in situ hybridization correlates with protein expression by immunohistochemistry and is associated with tumor progression. Virchows Arch. 2017 Jan;470(1):91-8.

31 Kim GE, Kim NI, Park MH, Lee JS. B7-H3 and B7-H4 expression in phyllodes tumors of the breast detected by RNA in situ hybridization and immunohistochemistry: association with clinicopathological features and T-cell infiltration. Tumour Biol. 2018 Nov;40(11): 1010428318815032.

32 Kim GE, Kim JH, Lee KH, Choi YD, Lee JS, Lee JH, et al. Stromal matrix metalloproteinase-14 expression correlates with the grade and biological behavior of mammary phyllodes tumors. Appl Immunohistochem Mol Morphol. 2012 May;20(3):298-303.

33 Dong Q, Ma X. B7-H4 expression is associated with tumor progression and prognosis in patients with osteosarcoma. BioMed Res Int. 2015;2015:156432.

34 Allred DC, Harvey JM, Berardo M, Clark GM. Prognostic and predictive factors in breast cancer by immunohistochemical analysis. Mod Pathol. 1998 Feb;11(2):155-68.

35 Wolff AC, Hammond ME, Schwartz JN, Hagerty KL, Allred DC, Cote RJ, et al.; American Society of Clinical Oncology; College of American Pathologists. American Society of Clinical Oncology/College of American Pathologists guideline recommendations for human epidermal growth factor receptor 2 testing in breast cancer. J Clin Oncol. 2007 Jan;25(1):118-45.
36 Bae YK, Gong G, Kang J, Lee A, Cho EY, Lee JS, et al.; Breast Pathology Study Group of Korean Society of Pathologists. HER2 status by standardized immunohistochemistry and silver-enhanced in situ hybridization in Korean breast cancer. J Breast Cancer. 2012 Dec; 15(4):381-7.

37 Salgado R, Denkert C, Demaria S, Sirtaine N, Klauschen F, Pruneri G, et al.; International TILs Working Group 2014. The evaluation of tumor-infiltrating lymphocytes (TILs) in breast cancer: recommendations by an International TILs Working Group 2014. Ann Oncol. 2015 Feb;26(2):259-71.

38 Madden SF, Clarke C, Gaule P, Aherne ST, O’Donovan N, Clynes M, et al. BreastMark: an integrated approach to mining publicly available transcriptomic datasets relating to breast cancer outcome. Breast Cancer Res. 2013;15(4):R52.

39 Fauci JM, Straughn JM Jr, Ferrone S, Buchsbaum DJ. A review of B7-H3 and B7-H4 immune molecules and their role in ovarian cancer. Gynecol Oncol. 2012 Nov; 127(2):420-5.

$40 \mathrm{Xu} \mathrm{H}$, Chen X, Tao M, Chen K, Chen C, Xu $\mathrm{G}$, et al. B7-H3 and B7-H4 are independent predictors of a poor prognosis in patients with pancreatic cancer. Oncol Lett. 2016 Mar; 11(3):1841-6.

41 Tang P, Tse GM. Immunohistochemical surrogates for molecular classification of breast carcinoma: a 2015 update. Arch Pathol Lab Med. 2016 Aug;140(8):806-14.

42 Lee A, Djamgoz MB. Triple negative breast cancer: emerging therapeutic modalities and novel combination therapies. Cancer Treat Rev. 2018 Jan;62:110-22. 